\title{
Seismic Assessment of St James Church by Means of Pushover Analysis - Before and After the New Zealand Earthquake
}

\author{
Ana S. Araújo*, Paulo B. Lourenço, Daniel V. Oliveira and João Leite
}

Department of Civil Engineering, University of Minho, Azurém, P-4800-058 Guimarães, Portugal

\begin{abstract}
The paper presents a numerical study for the seismic assessment of the St James Church in Christchurch, New Zealand affected by the recent 2011 earthquake and subsequent aftershocks. The structural behavior of the Church has been evaluated using the finite element modelling technique, in which the nonlinear behavior of masonry has been taken into account by proper constitutive assumptions. Two numerical models were constructed, one incorporating the existing structural damage and the other considering the intact structure. The validation of the numerical models was achieved by the calibration of the damaged model according to dynamic identification tests carried out in situ after the earthquake. Non-linear pushover analyses were carried out on both principal directions demonstrating that, as a result of the seismic action, the Church can no longer be considered safe. Pushover analysis results of the undamaged model show reasonable agreement with the visual inspection performed in situ, which further validates the model used. Finally, limit analysis using macro-block analysis was also carried out to validate the main local collapse mechanisms of the Church.
\end{abstract}

Keywords: Church, Finite Element Method (FEM), Masonry, New Zealand Earthquake, Pushover Analysis, Seismic Assessment.

\section{INTRODUCTION}

It is well known from past and recent earthquakes that traditional masonry buildings, particularly if inadequately tied, do not respond well to strong dynamic demands such as earthquakes. These natural catastrophes have always represented the main cause of damage and loss of cultural heritage [1], stressing the need of safety evaluation of old buildings in seismic zones. Masonry buildings are generally able to carry the vertical loads in a safe and stable way [2], but from a structural point of view, they tend to fail to respond well to horizontal loads, due to masonry's very low tensile strength. Many areas around the world are characterized by high level of seismic hazard and, as a result, the vulnerability of ancient masonry structures is often relevant [1]. Lately, the conservation of heritage buildings is an issue receiving a growing interest in the engineering community, resulting in an increase of research interest as a way to preserve one's own culture.

Performing a structural analysis of a heritage masonry construction is a complex and difficult task [3] and [4], given the unknowns about the condition of the building, its history and building phases, the morphology of structural elements, the connection between structural elements, among other aspects. In the last few years, due to increasing awareness in society about heritage buildings, there has been a major advance in modelling and analysis techniques. Many compu tational tools for the assessment of the mechanical behavior

*Address correspondence to this author at the Department of Civil Engineering, University of Minho, Azurém, P-4800-058 Guimarães, Portugal; Tel: +351 253510200; Fax: +351 253510217;

E-mails: ana.araujo@civil.uminho.pt,id3318@alunos.uminho.pt of historic structures are currently available and can be successfully used. Furthermore, different methodologies have been proposed for the seismic assessment of masonry buildings, e.g. [5-15].

Still, the Recommendations for the Analysis, Conservation and Structural Restoration of Architectural Heritage, approved by ICOMOS [16] state that structures of architectural heritage, by their nature and history, are a challenge for seismic analysis. The recommended methodology by ICOMOS for the assessment of ancient structures requires firstly data acquisition, including e.g. geometry and historical information of the building, and secondly the inspection of the present condition of the building by means of visual inspection and experimental tests. Afterwards, numerical modelling is performed to simulate and assess the seismic behavior of the structure and, at last, the safety evaluation is made and the design of the remedial measures, if required, is carried out.

Masonry is a complex material to model due to the inherent anisotropy and variability of properties. Only a few authors implemented constitutive non-linear models that are able to consider different strength and deformation capacity along the material axes, e.g. [17] for finite elements and [18] for limit analysis. These models are not widely disseminated and can be hard to apply in traditional buildings given the difficulties to characterize the existing fabric with a high level of detail. An alternative, lowest-complexity level, solution is to adopt simple geometrical indices, e.g. [19], to make a first, non-binding, screening of seismic assessment. In this paper nonlinear finite element modelling (FEM) analyses are performed to study the structural behavior of a Church in New Zealand. St. James Church is located in Christchurch, 
New Zealand, and has suffered structural damage with the recent earthquake on 22th February 2011 and subsequent aftershocks. As detailed in situ inspection was carried out (visually, by coring and by dynamic identification), a first relevant contribution of this paper is model updating of a heavily damaged structure. Subsequently, the paper presents the results of the seismic assessment of the Church, by means of two numerical models, being one damaged and the other one undamaged. The aim of performing pushover analysis in the undamaged model is to assess, on one hand the quality of the numerical model by comparing the results with the crack pattern currently observed, and on the other hand to clearly understand the seismic behavior of the Church subjected to a seismic action. The double validation of the model by dynamic identification and damage pattern increases the reliability of the conclusions and of the final safety assessment of the damaged church.

\section{HISTORICAL SYNOPSIS}

The Church building was started in 1923 to provide a permanent center for Anglican worship. The architects were the brothers Alfred and Sidney Luttrell who together designed a number of notable New Zealand buildings. For St James Church, they adopted a simple early English Gothic style (see Fig. 1). On the right hand side of the nave a memorial headed "Pro Patria" lists the names of the men of Riccarton, a suburb of Christchurch, who died in the 1914-1918 war. In the 1940's the Church grounds were redesigned. The hedge fronting Riccarton Road was removed and a curved driveway lined with roses and centring on another war memorial (this time to the soldiers of World War II) was put down. Thus the original concept of a memorial Church was continued.

The Church has rectangular shape with a long nave that constitutes the main body of the building with $27.0 \mathrm{~m}$ long and $10.3 \mathrm{~m}$ wide. There are other secondary compartments that define the exterior shape of the building, as the entrance, the vestry, the tower, and a sort of side chapel where the organ is located (see plant of the Church in Fig. 2). The building has a large number of buttresses in all façades and corners, which seems to indicate a clear earthquake concern. The two naves that compose the Church have different heights, with a height of $10.5 \mathrm{~m}$ for the main nave and a height of $9 \mathrm{~m}$ for the altar nave. The tower is the tallest element of the Church with a height of $15 \mathrm{~m}$. The roof consists of a series of wooden trusses, spaced every $3 \mathrm{~m}$ and aligned with the external buttresses position (see Fig. 3).

During the in situ inspection, specimens were taken from the walls in order to know their constitution (Fig. 4). The Church is usually referred to as an unreinforced masonry structure, coated with Halswell stone, with facings of cream Oamaru stone and plastered brick on the inside [20]. In fact, the wall specimens indicate that three layers of materials are present, brick on the inside of the wall, weak concrete in the inner core and stone in the outside façade.

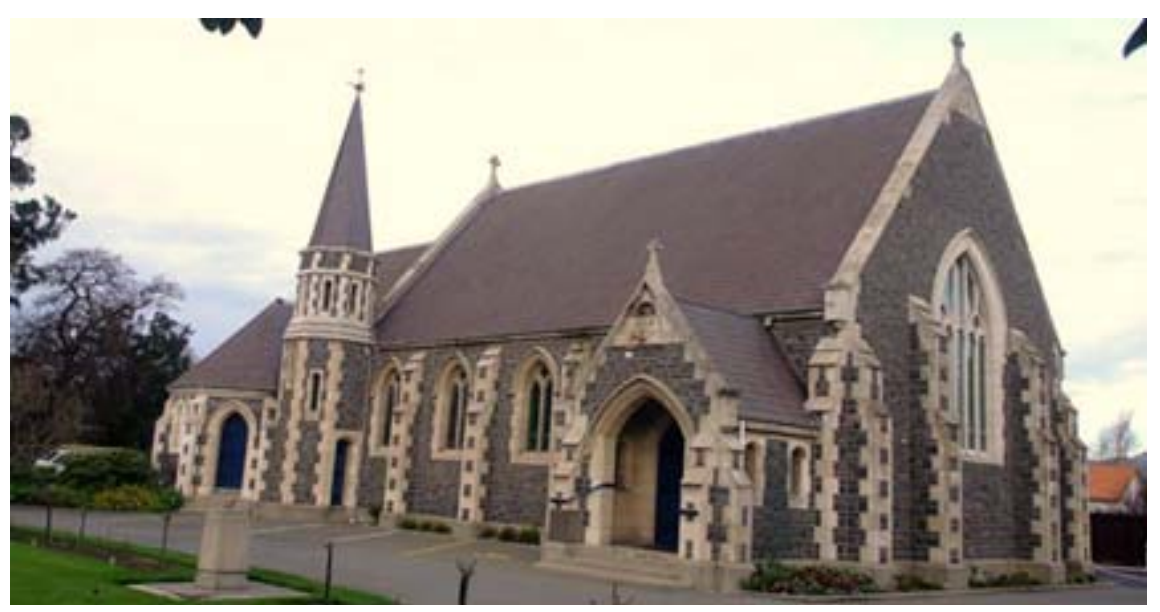

Fig. (1). General view of St. James Church.

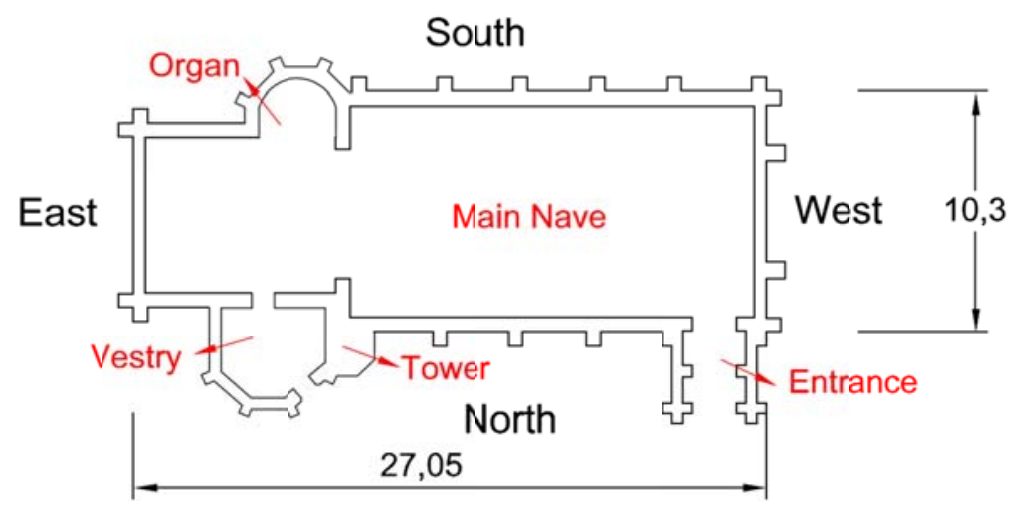

Fig. (2). Plant of the Church with the areas that compose the building and the main dimensions, in meters. 


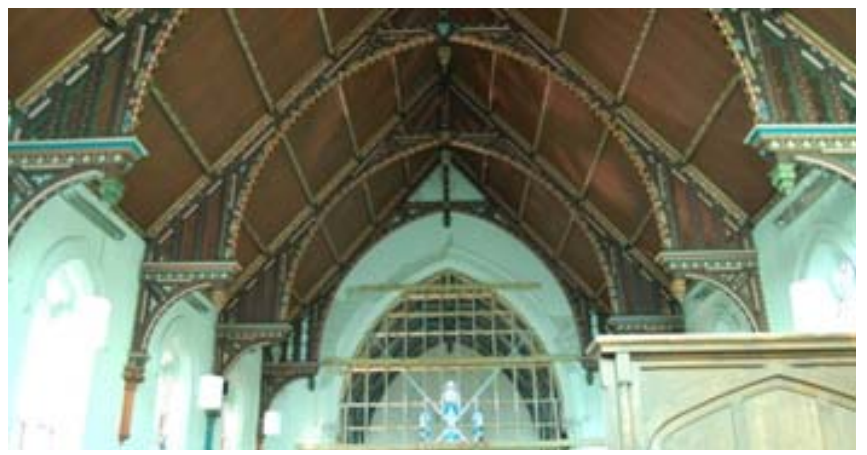

Fig. (3). Roof structure.

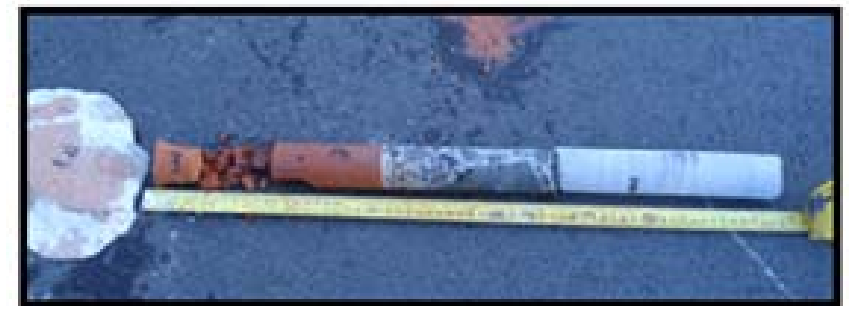

Fig. (4). Specimens of the walls.

\section{VISUAL INSPECTION}

The Church has suffered structural and non-structural damage as a consequence of $22^{\text {th }}$ February 2011 earthquake [21]. A visual inspection was carried out and the main damage visible in the structure is presented in Fig. (5). The most damaged areas are the transversal façades, east and west, and the triumphal arch located in the middle of the two naves. Several cracks developed on the east wall both in the outer façade and inside of the Church (see Fig. 5a). It can be observed that the areas with more damage are aligned with the height at which the buttresses end, which indicates therefore an inadequate design with a strong geometrical discontinuity. Some thin cracks with a width smaller than $1 \mathrm{~mm}$ have developed between the window and the base of the wall. However, there is a large horizontal crack, about $5 \mathrm{~mm}$ wide, above the alignment of the buttresses, both in the façade and inside the building. Some stone blocks have moved at this level. In conclusion, damage is present and is mostly due to out-of-plane movements, even if some diagonal cracks due to in-plane movements are also observed.

Regarding the other transversal wall, the west façade, the crack pattern is presented in Fig. 5b). One relatively large horizontal crack running across the wall is again visible in the alignment where the main buttresses finish. This crack is clearly seen both from the interior and exterior side and is about $4 \mathrm{~mm}$ wide. Similarly to the east wall, a detachment of the coating around this horizontal crack is clearly visible.

The longitudinal walls do not have much earthquakerelated damage, as shown in Fig. 5c) and d). The existing damage consists of a few cracks around windows and a horizontal crack on the top of the wall, which develops between the wooden trusses that compose the roof structure. The cracks in the base of the windows are developing along bed and head joints in stair-stepped manner up to the floor. The cracks in these walls are relatively thin, with a width smaller than $1 \mathrm{~mm}$, in comparison to the east and west walls.
In the triumphal arch the damage is severe as shown in Fig. 5e). In the discontinuities of this arch, i.e. at the intersection of the walls with the roof and the top of the trusses, large cracks are formed. Furthermore, a crack has appeared throughout the arch, following its ogival shape. Significant damage is visible in the wall cladding near the cracks. The top part of the chancel arch gable exhibits out of plane displacements.

Finally, it is noted that the horizontal cracks are accompanied by spalling of the limestone facings, and large areas of plaster have fallen from the chancel arch, and the east and west gable walls.

The walls in the transversal direction are the most damaged, allowing the assumption that this is the weakest direction. Also, the images and the damage observed indicate that the roof structure is not tightly linked to them (the gable walls), and it is not stiff enough to adequately tie the longitudinal walls.

\section{NUMERICAL MODEL}

A numerical model of the structure of St. James Church was constructed in order to properly simulate the structural behavior of the building. The model was prepared taking into consideration the geometrical data and the structural damage found in the building. The configuration of the model attempts to reproduce the structural behavior of the Church, while adopting the necessary simplifications.

The numerical model was prepared using the DIANA [22] software using the geometrical information gathered from historical documents and in situ survey. The church geometry was prepared using a 3D model with the two main naves, the three secondary compartments and the tower. The walls were simulated as shell elements and the timber trusses of the roof were simulated as beams elements. The roof sheeting and transverse beams between the timber trusses were also simulated with shell elements. The model aims also at reproducing the structural damage present. Due to the extensive damage observed in the triumphal arch and gable walls, one can assume that the roof structures are not rigidly connected with all transversal walls. The mesh was automatically generated by DIANA and then manipulated and controlled in order to obtain a good quality mesh. The areas with shell elements are discretized in both quadrilateral 8 nodes (CQ40S) and triangular 6 nodes elements (CT30S) depending on the geometry. With respect to the beam trusses, these are discretized using 3 nodes beam elements (CL18B). The generated mesh resulted in 29,648 nodes and 10,588 elements, see Fig. 6a). Concerning the materials, these can be divided into four in the numerical model: "masonry" in almost all of the walls (in fact, the material is made of three different layers), concrete in two slabs (one of the secondary compartments and another in the tower) and wood in the roof structure, see Fig. 6b).

\section{CALIBRATION OF THE NUMERICAL MODEL}

With the aim of correctly characterizing the structural behavior of the Church, besides the visual inspection, dynamic identification tests were carried out. These tests allowed obtaining the vibration modes of the building and their frequencies. The finite element model dynamic characteristics can now be compared with the experimental ones. The numerical model attempts to reproduce the general structural 

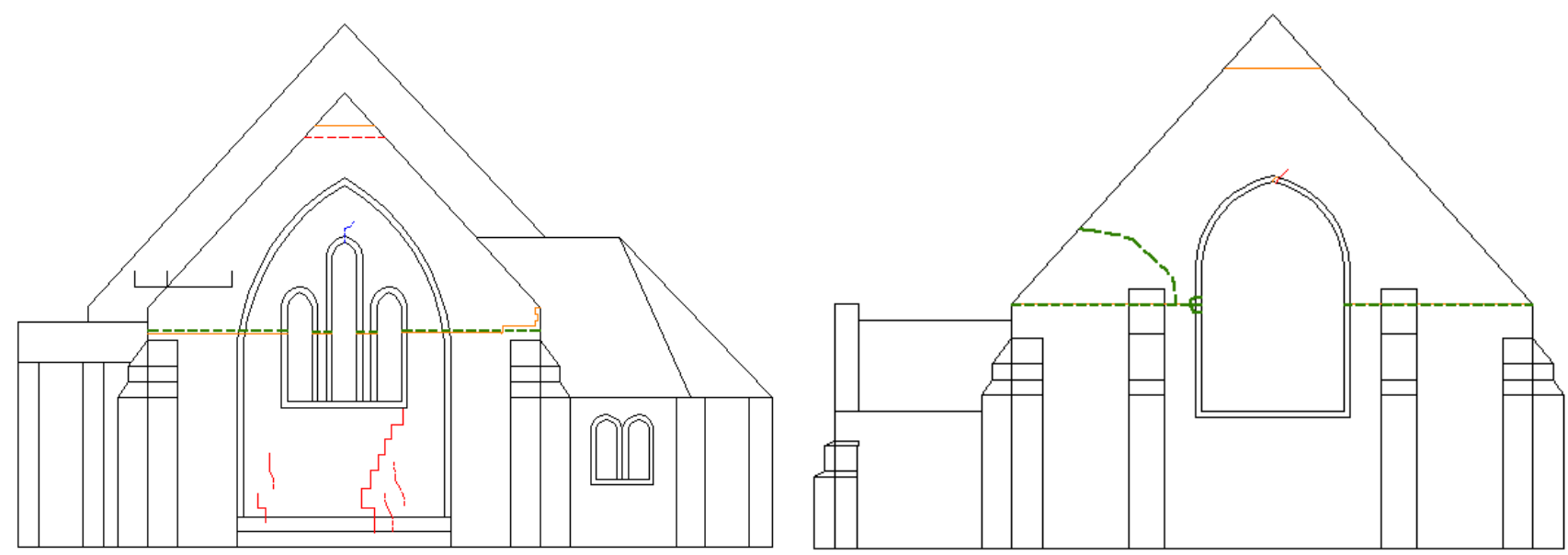

a) b)

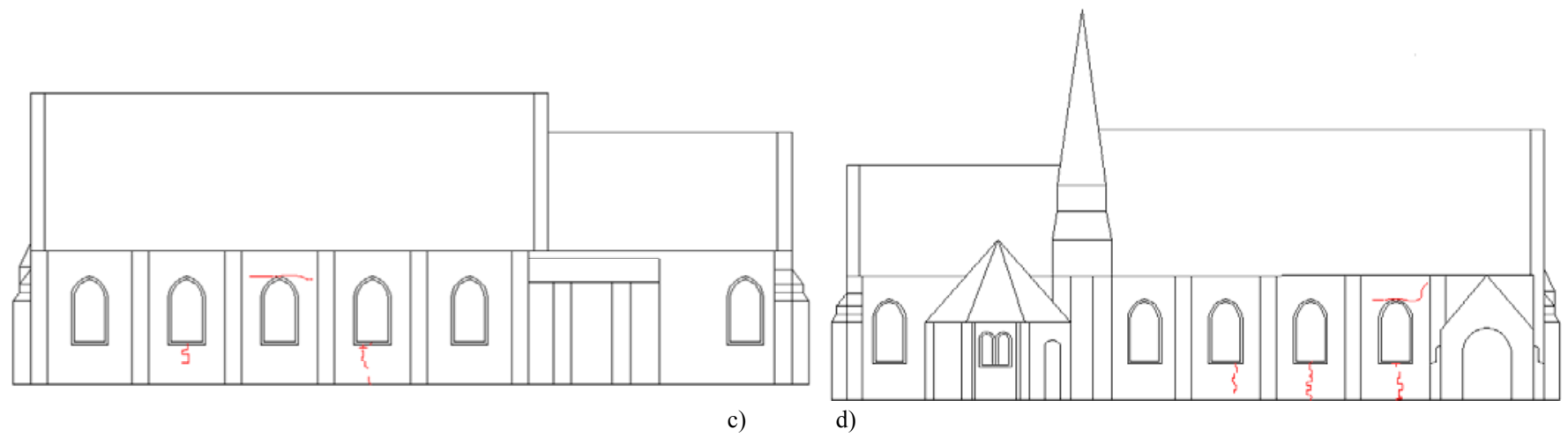

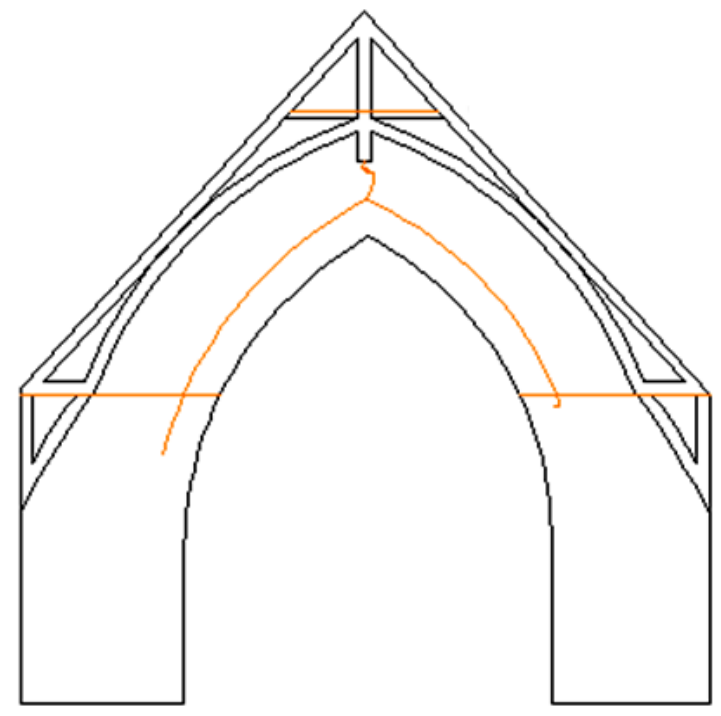

e)

\section{Legend:}

\begin{tabular}{|l|c|}
\hline & width smaller than $1 \mathrm{~mm}$ \\
\hline & width between $1 \mathrm{~mm}$ and $3 \mathrm{~mm}$ \\
\hline & width between $3 \mathrm{~mm}$ and $5 \mathrm{~mm}$ \\
\hline & undefined width \\
\hline- & cracks inside the Church \\
\hline
\end{tabular}

f)

Fig. (5). Crack pattern; a) East wall, b) West wall, c) South wall, d) North wall, e) Triumphal arch f) Crack legend.

behavior of the church considering the existing damage. A first analysis of the shapes of the obtained experimental vibration modes, indicate that the two cracks identified in the east and west crack patterns have a large influence in the structural behavior of these walls. These cracks are horizontal and cross the entire width of the facade wall. As such, these cracks are modelled as a discontinuity in the wall, using elements with smaller thickness associated with the crack positions. The model can then be calibrated considering these two main cracks visible in the experimental results and in the damage identification.

Concerning the elastic properties of the materials, a constant Poisson's ratio $v$ of 0.2 was used for all materials. The 

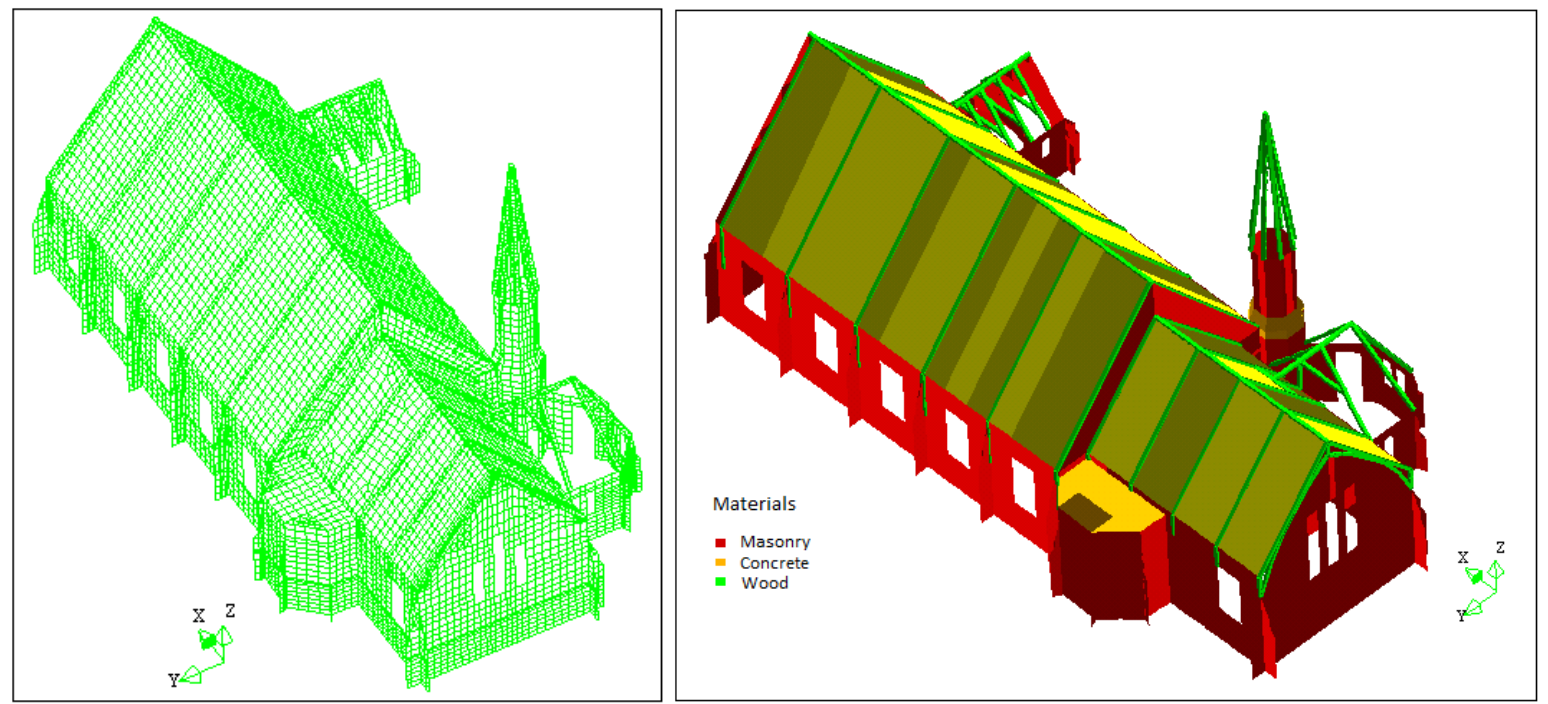

Fig. (6). Numerical model; a) Mesh b) Materials.

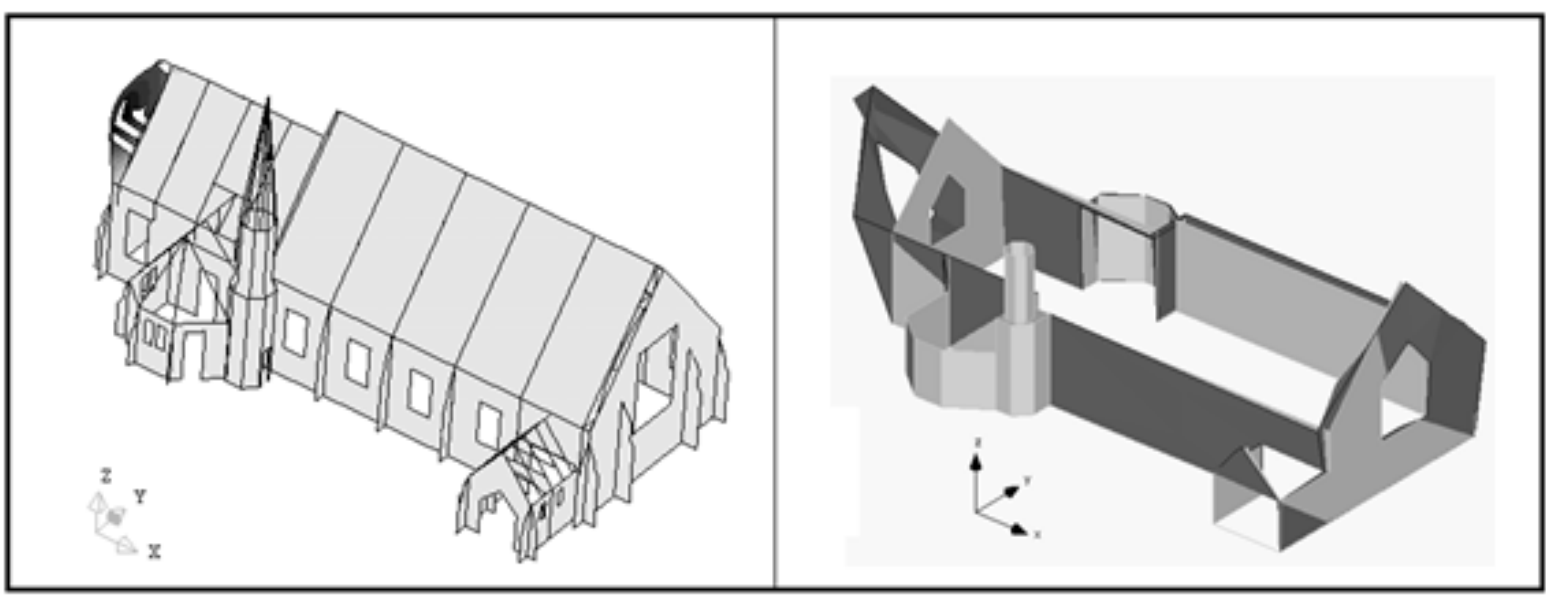

Fig. (7). Comparison between the $1^{\text {st }}$ vibration mode of the numerical and the experimental.

usual elasticity modulus $E=30 \mathrm{GPa}$ for concrete was used, while a value of $\mathrm{E}$ equal to $12 \mathrm{GPa}$ was assumed for wood. For masonry, the value of the elasticity modulus is to be obtained from the model updating using the dynamic identification values. The chosen parameters for calibration of the model are then the elastic modulus of masonry and the element thickness of the two main cracks. The first three natural frequencies and mode shapes of the models were based on the frequency response functions (FRFs), phases and coherences, estimated through traditional methods of signal analysis [23]. The model was calibrated using MATLAB [24], optimizing the residuals formed with calculated and experimental frequencies and mode shapes, see e.g. [25]. As such, the frequency error and the Modal Assurance Criterion (MAC), i.e. a normalized comparison between numerical and experimental mode shapes such that a unit value indicates perfect match, are calculated for subsequent iterations. By minimizing the errors, the best fit for frequencies and MACs can be found, see Table 1. The optimized model, in comparison to the experimental value, has an average frequency error lower than $5 \%$ and an average MAC of $76 \%$. These are rather satisfactory values given the non-homogenous nature of the material and the existing damage.
The optimized parameters were the following: $E$ of masonry equal to $9.43 \mathrm{GPa}$, element thickness of $1.5 \mathrm{~cm}$ for the crack in the east wall and element thickness of $22.7 \mathrm{~cm}$ for the crack in the west wall. The achieved elastic modulus seems acceptable due to the good quality of the masonry and the inner concrete core. The thicknesses for the elements representing the horizontal cracks are rather different, with a very low value for the east wall. This is due to the extensive damage verified on this wall.

A visual comparison in terms of mode shapes can now performed. The first vibration mode is mainly the out-ofplane displacement of the east wall and Fig. (7) presents the comparison between the experimental and the numerical shapes, which show excellent agreement as also given by the MAC value close to the unit value. The second vibration mode is related mainly with the west wall, also with an outof-plane displacement, and both experimental and numerical results are shown in Fig. (8). Again, very good agreement is found, with a slightly lower MAC value. Finally, the third vibration mode concerns predominantly the west wall with double curvature, as shown in Fig. (9). The agreement between the numerical and experimental shape is reasonable, 
Table 1. Results from Dynamic Calibration

\begin{tabular}{|c|c|c|c|c|c|c|c|}
\hline \multirow{2}{*}{\multicolumn{2}{|c|}{ Experimental - Frequencies $(\mathrm{Hz})$}} & \multicolumn{6}{|c|}{ Numerical Model } \\
\hline & & \multicolumn{2}{|c|}{ Frequencies (Hz) } & \multirow{2}{*}{$\begin{array}{c}\text { Error (\%) } \\
0,2\end{array}$} & Average error (\%) & MAC (\%) & Average MAC (\%) \\
\hline Mode 1 & 11,0 & Mode 1 & 11,0 & & \multirow{3}{*}{4,8} & 92,5 & \multirow{3}{*}{75,7} \\
\hline Mode 2 & 12,5 & Mode 2 & 11,2 & 10,3 & & 79,1 & \\
\hline Mode 3 & 17,8 & Mode 3 & 17,2 & 3,8 & & 55,5 & \\
\hline
\end{tabular}

even if the movement in the east wall is not replicated by the numerical model.

\section{PUSHOVER ANALYSES}

Pushover analysis is a non-linear static structural analysis method, commonly used for the seismic assessment of existing masonry buildings and has been introduced in many seismic codes, such as [12] and [26]. This analysis includes material nonlinear behavior and the seismic action that is simulated by static horizontal forces. Pushover analysis consists of applying an incremental monotonic loading on the structure in order to determine its ability to resist to seismic actions, and has been gaining significance over recent years as a tool for the assessment of masonry structures, e.g. [27] and [28].

As recommended in [4], a uniform or mass proportional pushover approach is carried out in the main axis directions ( $\mathrm{X}$ and $\mathrm{Y}$ ), one for positive and one for the negative direction. As most of the non-linearities are expected to concentrate in the masonry, only this material is considered with non-linear behavior. The non-linear behavior of the masonry is modeled by the adoption of a constitutive model based on total strain, the Total Strain Fixed Crack model. This model describes the tensile and compressive behavior of the masonry with one stress-strain relationship [22] and has been used successfully in many applications to complex masonry

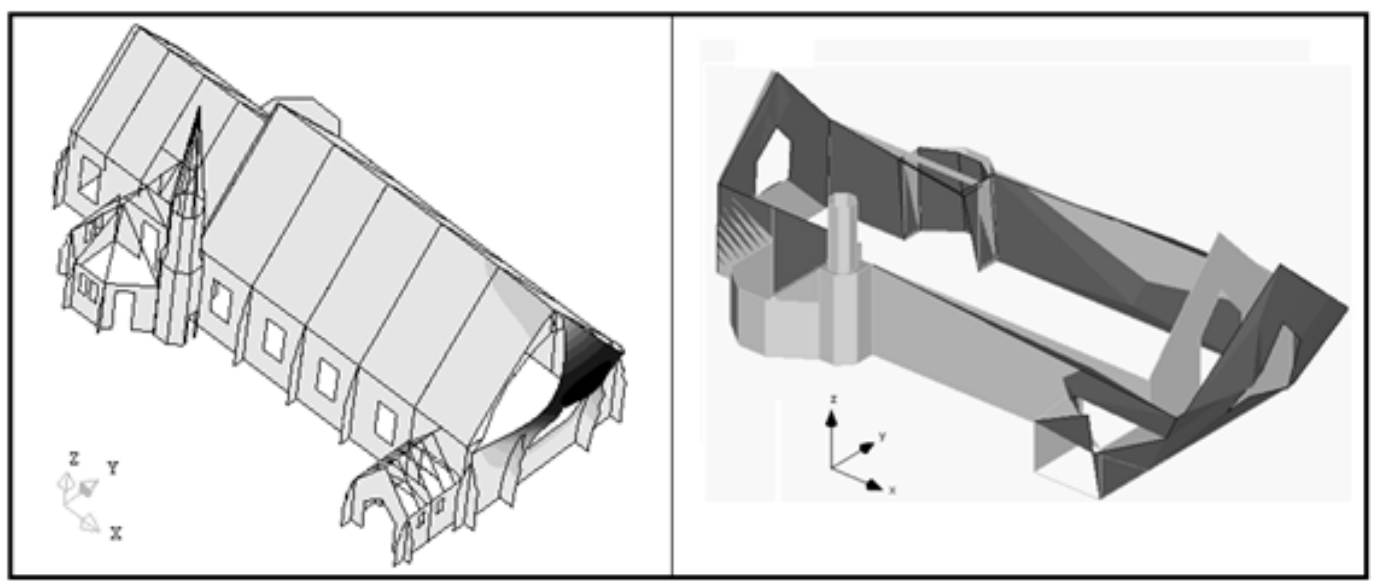

Fig. (8). Comparison between the $2^{\text {st }}$ vibration mode of the numerical and the experimental.

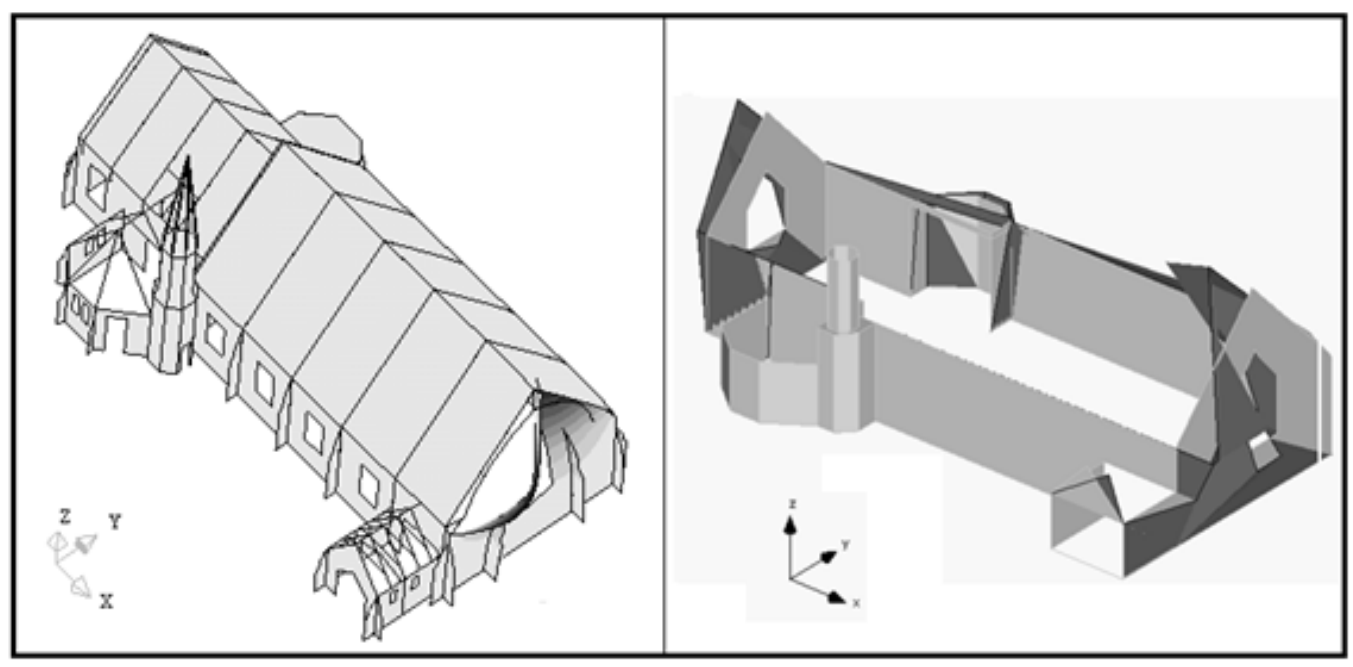

Fig. (9). Comparison between the $3^{\text {st }}$ vibration mode of the numerical and the experimental. 
structures, e.g. [29] and [30]. The inelastic stress-strain diagrams selected were an exponential relationship for tension and a parabolic relationship compression (see Fig. 10). The nonlinear properties for the masonry constitutive model were calculated based on recommendations from Lourenço [31], according to the elastic modulus previously calibrated (see Table 2). Here $f_{c}$ is the masonry compressive strength, $G_{c}$ is the fracture energy in compression, $f_{t}$ is the masonry tensile strength, $G_{t}$ is the tensile fracture energy and $\beta$ is the shear retention factor. The solution procedures used the regular Newton-Raphson method and an energy convergence criterion, with a tolerance of 0.001 .
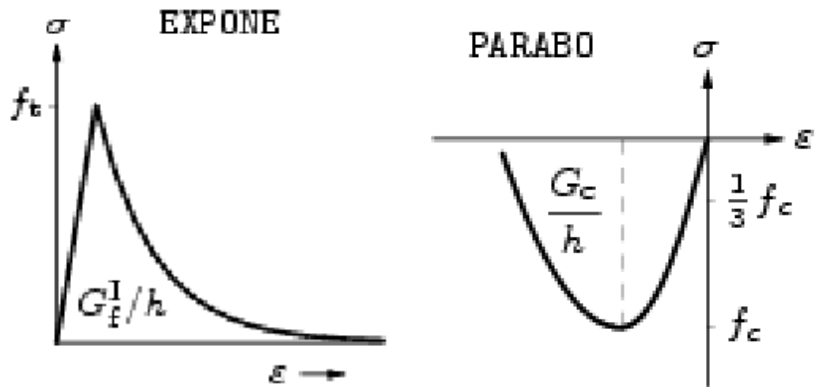

Fig. (10). Stress-strain diagrams for the non-linear behavior of masonry, tension and compression [22].

\subsection{Pushover Analysis after the 2011 Earthquake}

The first pushover analyses were performed in the numerical model that simulates the damaged church after the earthquake. Four analysis were carried out in the principal directions of the building $(+\mathrm{X},-\mathrm{X},+\mathrm{Y}$ and $-\mathrm{Y})$, as shown in Fig. (11). In a first stage the self-weight of the structure was applied and then the horizontal load was increased monotonically until full collapse.

Fig. (12) depicts the capacity curves for the gable walls, with a maximum load coefficient of $0.21 \mathrm{~g}$ in $+\mathrm{X}$ direction, with loss of the capacity of the east wall. As addressed before, the east wall has a very severe crack pattern and the west wall has more stiffness due to its configuration: the thickness is larger than the east wall and it has two more buttresses near the window. For a better understanding of the non-linear behavior of the structure, the principal tensile strains are plotted as an indicator of damage (Fig. 13). The concentrations of strains occur on the top of the tympanum. The pushover analysis in the $-\mathrm{X}$ direction provides similar results in terms of capacity and damage pattern. A possible interpretation of the collapse mechanism of the wall, as observed in true earthquakes, is shown in Fig. (14). The pre-

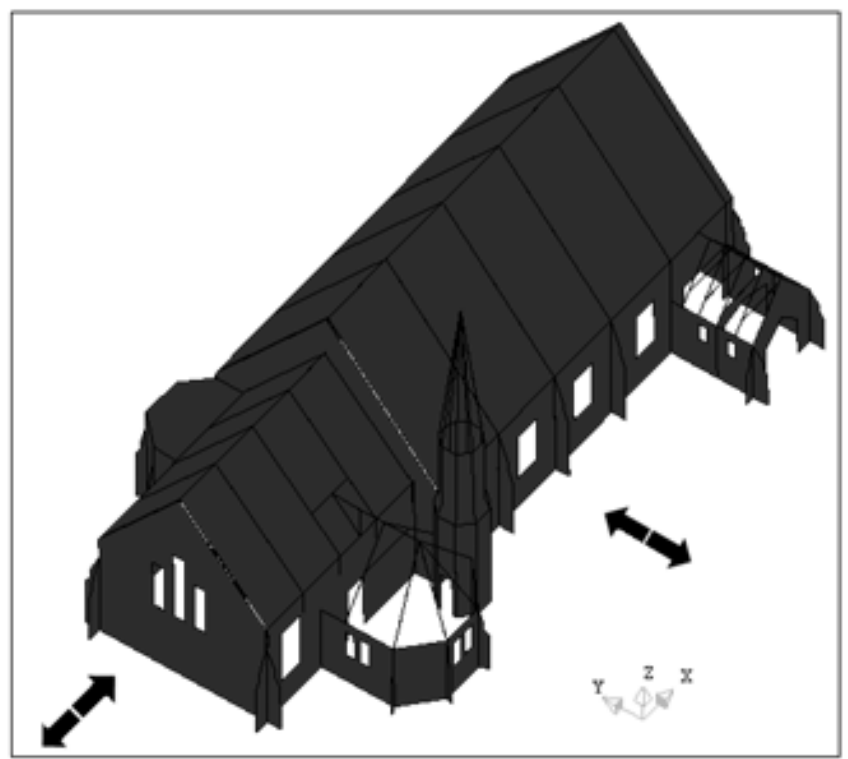

Fig. (11). Applied load direction in the principal axes directions.

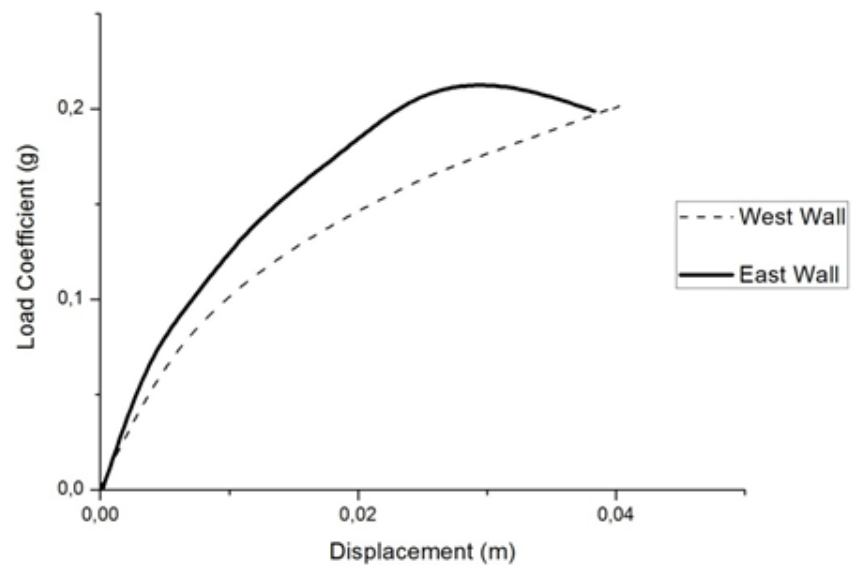

Fig. (12). Capacity curve of pushover analysis in $+X$ direction.

sented failure mode occurs with the detachment of the top of the tympanum of the east wall which can then lead to the out-of-plane collapse of the whole tympanum due to the preexistent horizontal crack.

The pushover analyses carried out in the other principal direction, $\mathrm{Y}$, prove that when the horizontal load is applied perpendicular to the longitudinal walls (north and south), the structure capacity increases, being able to reach a PGA of about $0.4 \mathrm{~g}$ (Fig. 15) significantly higher than the one attained

Table 2. Non-linear Mechanical Properties of Masonry

\begin{tabular}{|c|c|c|c|c|c|c|}
\hline $\mathbf{E}(\mathbf{G P a})$ & $\boldsymbol{v}(-)$ & $\mathbf{f}_{\mathbf{c}}\left(\mathbf{N} / \mathbf{m m}^{\mathbf{2}}\right)$ & $\mathbf{G}_{\mathbf{c}} \mathbf{( N / \mathbf { m m } )}$ & $\mathbf{f}_{\mathbf{t}}\left(\mathbf{N} / \mathbf{m m}^{\mathbf{2}}\right)$ & $\mathbf{G}_{\mathbf{t}}(\mathbf{N} / \mathbf{m m})$ & $\boldsymbol{\beta}(-)$ \\
\hline \hline 9.43 & 0.2 & 11.7 & 18.7 & 0.15 & 0.01 & 0.1 \\
\hline
\end{tabular}

Table 3. Results for Load Coefficient Using Limit Analysis

\begin{tabular}{|c|c|c|c|c|}
\hline & Bell Tower $\mathbf{Y}$ & East Wall X & West Wall X & Triumphal Arch Y \\
\hline \hline Load factor $(\alpha)$ & 0.221 & 0.141 & 0.176 & 0.229 \\
\hline
\end{tabular}




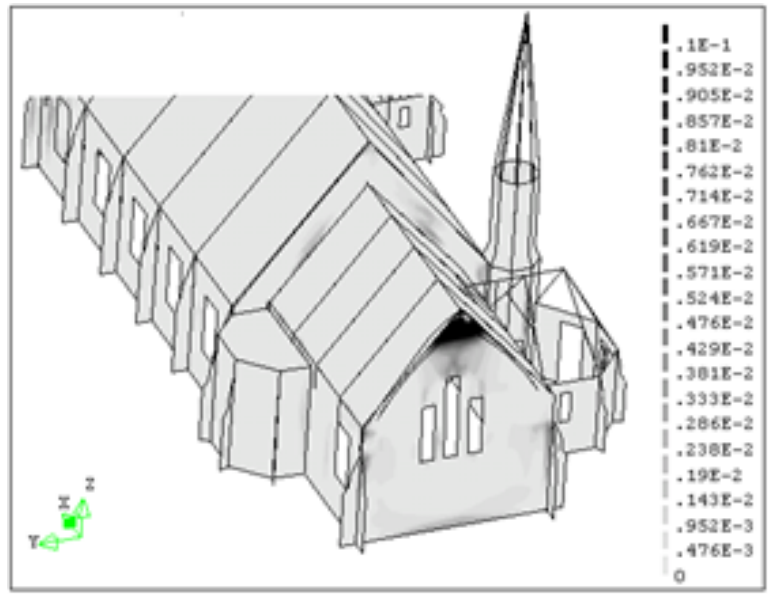

Fig. (13). Principal strains and collapse mechanism on the top of the shell elements ( $+\mathrm{X}$ direction).

by the $\mathrm{X}$ analyses. For the two loading signs, the results are similar, with a deformation mode involving the entire structure, see Fig. 16a). The maximum displacement occurs on the tower and in the region close to it, reaching a displacement about $0.15 \mathrm{~m}$ for the peak load. The principal strains at the maximum applied load are plotted in Fig. 16b), where two main damaged areas are clearly shown. One of the cracks is located on the east façade, near the buttress and opposite to the loading sign, while the other is visible in the triumphal arch. This last crack is possibly due to the large stiffness and stress differences between the nave and the tower. In fact, the formation of the crack along the connection allows the tower's independent movement and rotation. No significant damage is visible in the other walls.

Considering the results of all pushover analyses, it is evident that the capacity of the Church is limited by the pushover in $\mathrm{X}$ direction. The capacity of the building is almost symmetric $(0.21 \mathrm{~g}$ for $+\mathrm{X}$ direction, $0.20 \mathrm{~g}$ for the $-\mathrm{X}$ direction, $0.41 \mathrm{~g}$ for $+\mathrm{Y}$ direction and $0.42 \mathrm{~g}$ for $-\mathrm{Y}$ direction) and the its global capacity is determined by the low capacity of the east wall due to the pre-existing damage. The PGA requirement for the area was fixed at $0.3 \mathrm{~g}$ after the earthquake and the church requires repair or strengthening.

\subsection{Pushover Analysis before the 2011 Earthquake}

A set of pushover analysis were performed in a numerical model that simulates the undamaged structure, in order to discuss if a repair strategy, e.g. to reinstate the original ca-

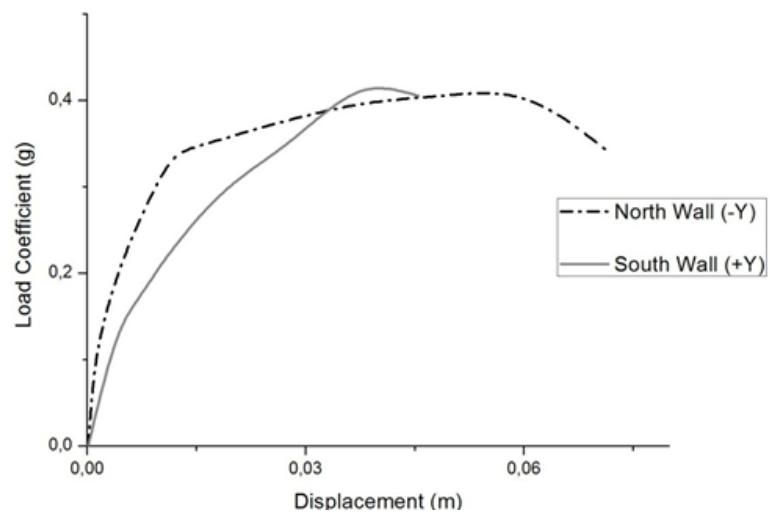

Fig. (15). Capacity curve of pushover analysis in $\mathrm{Y}$ direction.

pacity of the building, would be enough to comply with the code requirements. In addition, these analyses allow further validation of the model, by comparison between the new results and the crack pattern obtained after the 22th February 2011 earthquake.

The new capacity curves are shown in Fig. (17), where it is shown now that the capacity in the $\mathrm{X}$ direction increased significantly, to values higher than $0.5 \mathrm{~g}$, while the capacity in the Y direction is kept about the same, meaning that the weakest capacity occurs for the Y direction. Concerning the pushover in $+\mathrm{X}$ direction the areas subjected to most relevant cracking are the buttresses and facades in the east and west ends, due to out-of-plane rotation, and the longitudinal walls, on the north and south façades, due to in-plane shear around the openings and the entrance, see Fig. (18). The analysis in the opposite loading sign $(-X)$ leads to concentration of damage in the east wall, see Fig. (19). In the Y pushover, damage is mostly induced by in-plane shear, with some concentration around the tower, as explained above, see also Figs. (20 and 21). Damage occurs in transverse walls and the triumphal arch.

The results of the pushover analysis considering the undamaged structure, before the earthquake, demonstrate that there is reasonable agreement between the crack pattern observed in the structure after the earthquake and the damage achieved numerically. The first aspect is the damage on all façades, and triumphal arch, which are both predicted to occur in the model, involving the weakest structural capacity. The damage in the north and south façades, and triumphal arch, seems to be nicely matched. Still, the damage in the west and east façade seem less well matched, as the
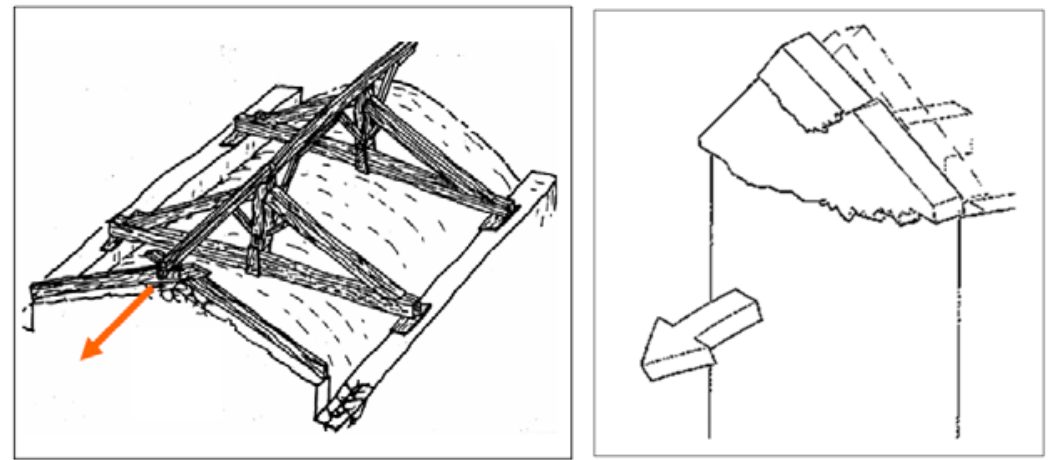

Fig. (14). Collapse mechanism in the tympanum of the east wall ( $+\mathrm{X}$ and $-\mathrm{X}$ direction). 


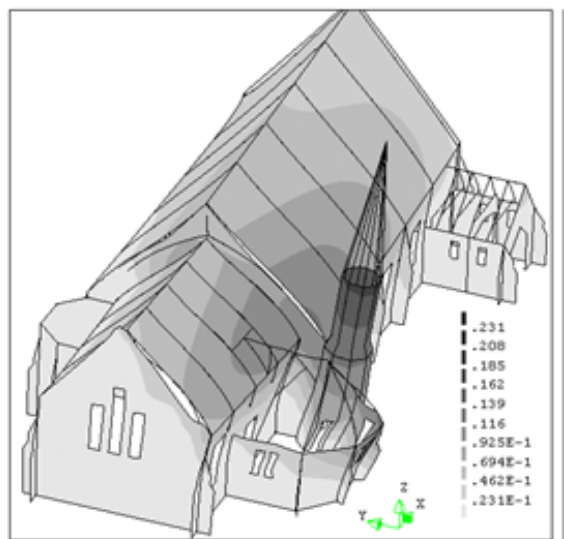

a)

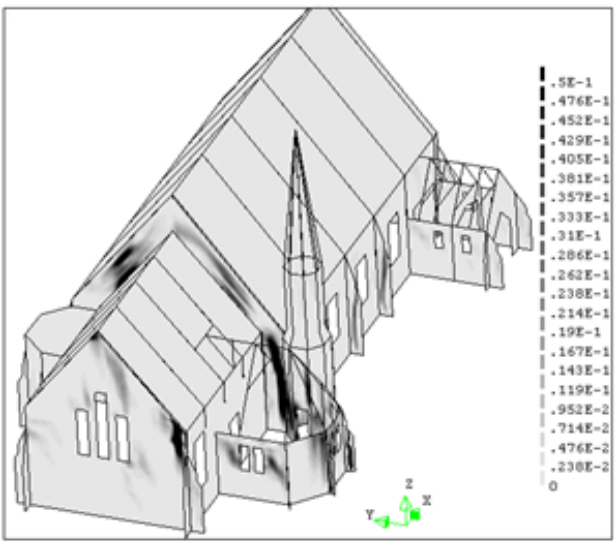

b)

Fig. (16). Results of the $-Y$ pushover analysis; a) Total displacements and deformed shape (scale factor =10) and b) Distribution of the principal strains.

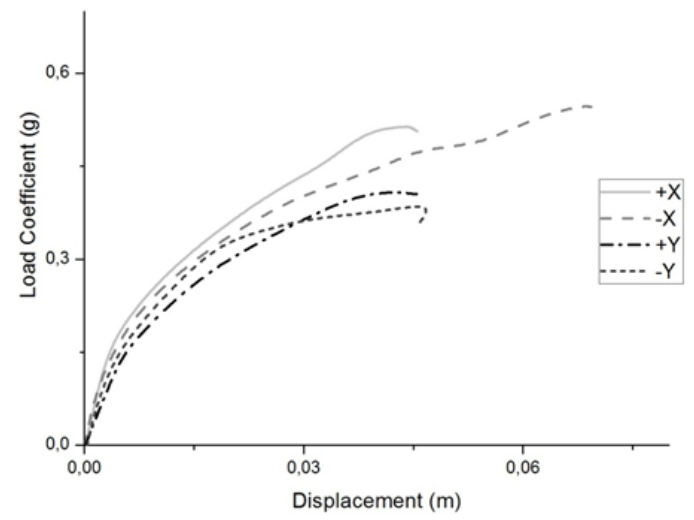

Fig. (17). Capacity curves for undamaged structure.

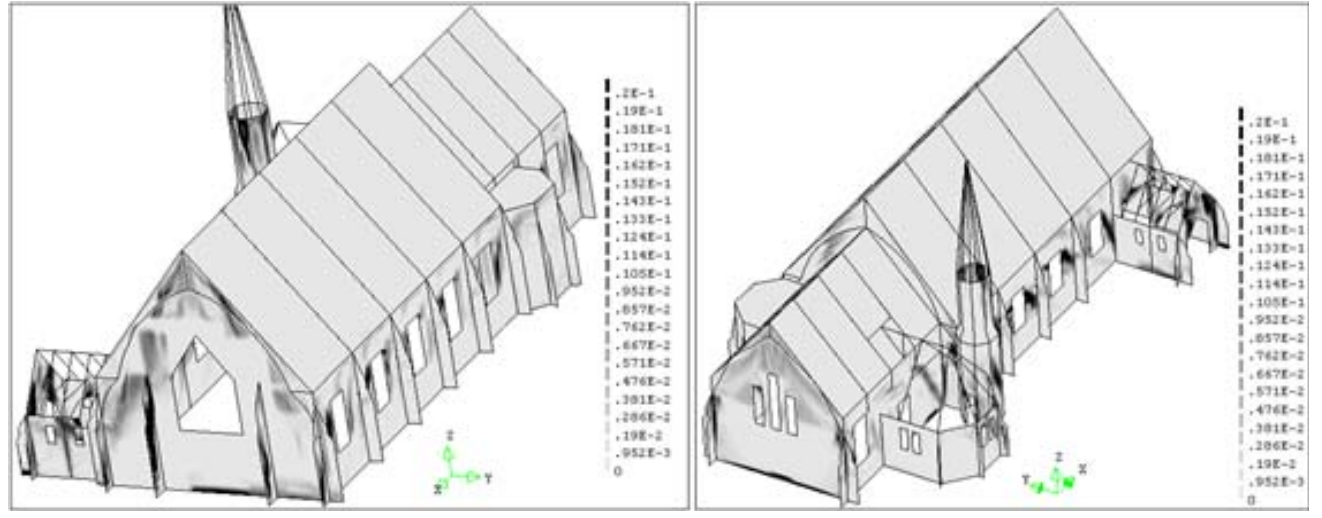

Fig. (18). Distribution of the principal strains ( $\mathrm{X}$ direction, undamaged structure).

earthquake damage seems to be mostly out-of-plane, mobilizing higher modes and possibly some hammering effect of the roof structure, while the numerical push-over damage is mostly in-plane. This is not unexpected, as the failure modes are difficult to predict correctly, if static pushover analysis methods are used for masonry structures without box effect, as clearly indicated by [4]. The numerical results also indicate that there is a good prediction of the model, in providing a major capacity reduction of the structure due to the observed damage, and that the structure would be reasonably safe in the original undamaged structure, as also confirmed by the fact that the structure survived the earthquake. The results also indicate that the original direction with the largest capacity (longitudinal) became after the damage, the direction with the weakest capacity. This is a somewhat striking conclusion, and again indicates that pushover analyses are possibly incorrect in terms of failure modes, requiring caution when applied in engineering applications.

\section{LIMIT ANALYSIS}

In existing masonry buildings local collapses often occur in case of an earthquake, generally due to loss of equilibrium of masonry parts, rather than a global failure mode associated with lack of integrity of the structure. Post-earthquake 


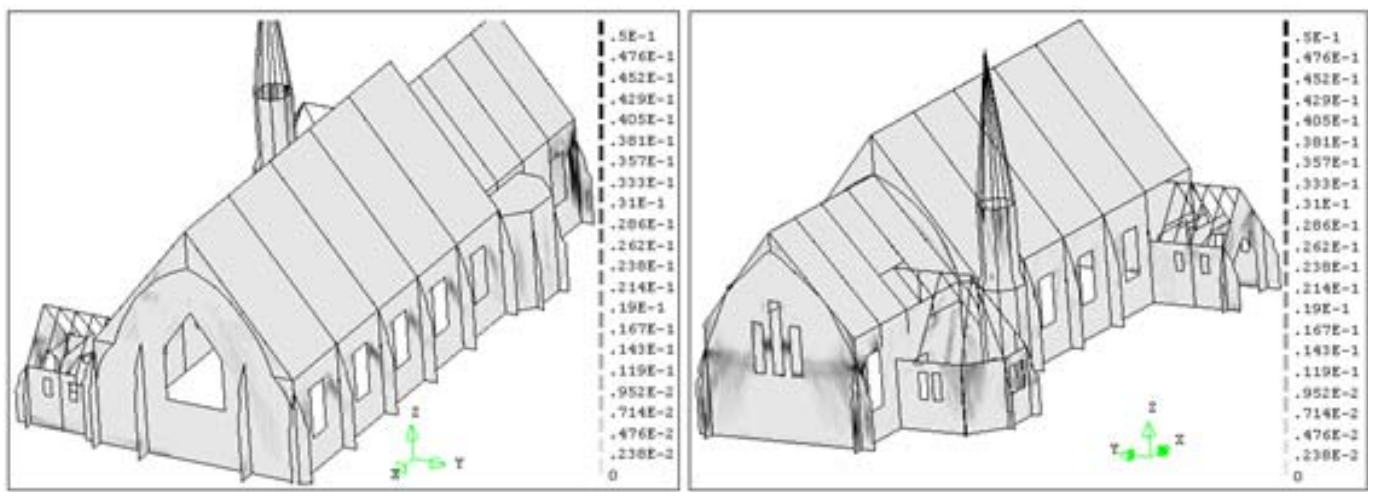

Fig. (19). Distribution of the principal strains (-X direction, undamaged structure).

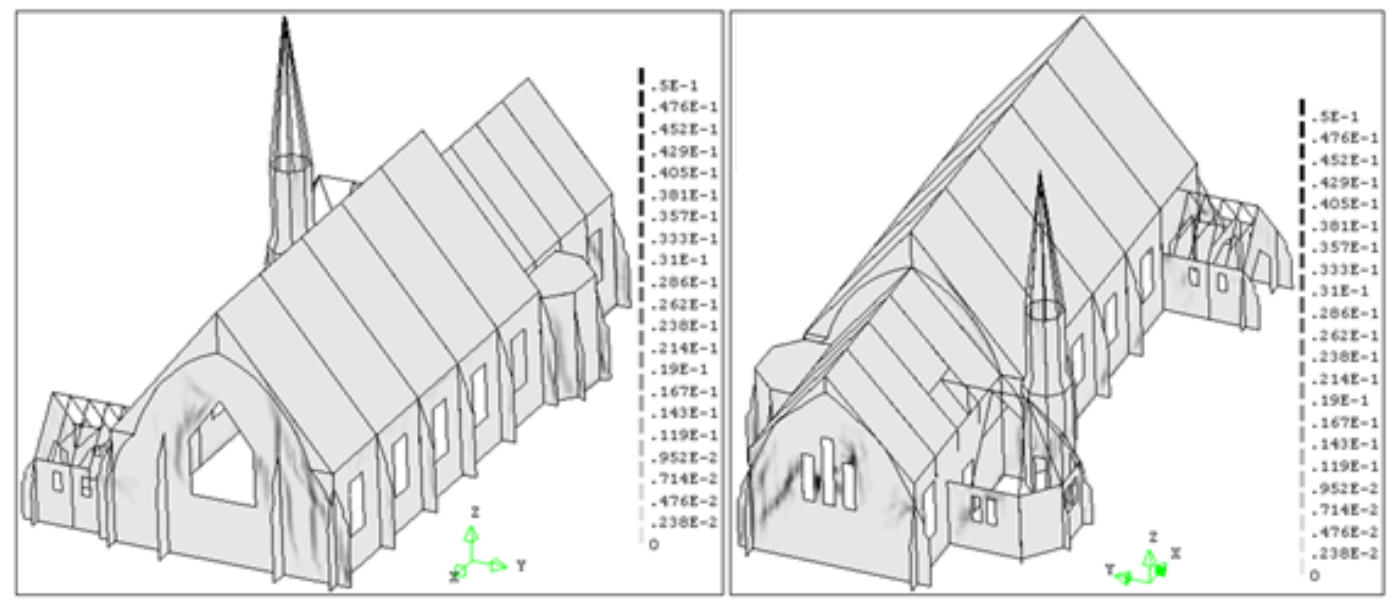

Fig. (20) Distribution of the principal strains ( $+Y$ direction, undamaged structure).

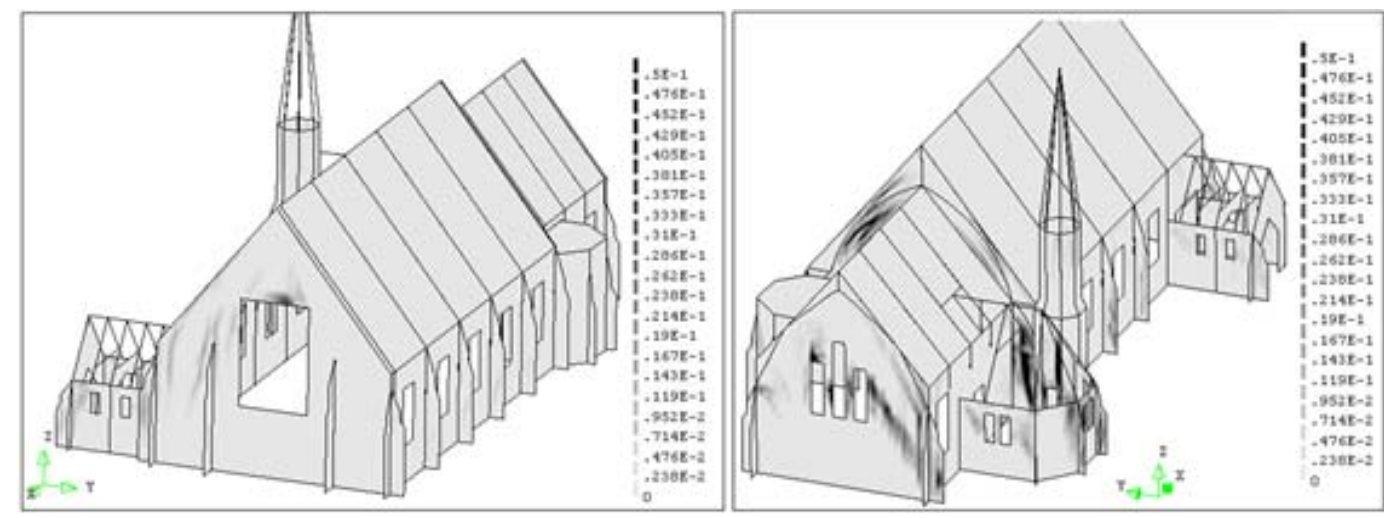

Fig. (21). Distribution of the principal strains (-Y direction, undamaged structure).

surveys and experimental research, conducted in the last few years regarding the effects of earthquakes on ancient buildings, allowed the compilation of the main local collapse mechanisms in an abacus in the form of graphical interpretation schemes (see $[32,33]$ ). These macro-block mechanisms allow the use of limit analysis for safety assessment and strengthening design [34-37]. The hypotheses usually adopted for the masonry behavior in this case are: no tensile strength, infinite compressive strength and absence of sliding at failure. Limit analysis can be regarded as a practical computational tool, since it only requires a low number of mechanical properties of the materials and can provide a good insight into the failure pattern and limit load $[35,38]$.
The limit analysis applied to St James Church follows the general macro-elements approach adopted listed in the abacus for churches. The collapse mechanisms assumed were selected also on the basis of the observed damage pattern, where applicable, and the numerical damage obtained through the non-linear analysis. Hence, four collapse mechanisms were defined for the Church. The first collapse mechanism includes the overturning of the whole bell tower structure along Y direction (see Fig. 22a). The other two out of plane mechanisms include the overturning of the east and west tympanums along $\mathrm{X}$ direction, behaving these elements as rigid blocks (see Fig. 22b) and c)). The kinematic limit analysis approach was applied to the rigid blocks defined, 
which allowed the evaluation of the horizontal action that activates the mechanism. The load coefficient $(\alpha)$ that activates the mechanism is calculated by applying the principle of virtual works and is presented in Table $\mathbf{3}$ for each mechanism.

The last collapse mechanism defined is an in-plane failure in the triumphal arch with the formation of plastic hinges. The triumphal arch is a recurrent structural element in Churches and has special importance in its seismic behavior [36, 39]. In this study the limit analysis approach was applied using the software Block developed by Orduna [35] and the obtained mechanism is presented in Fig. (23) with the formation of three plastic hinges. The obtained load coefficient was 0.229. Thus, considering the four studied collapse mechanism, the lowest load coefficient was obtained for the out of plane overturning of the east facade tympanum, with 0.141 . These results are compatible with the numerical ones in the way that the east wall is the one limiting the structural capacity of the Church, which was also verified in the pushover analysis after the earthquake damage. The simplification of the wall tympanum to a rigid block for the limit analysis is comparable in terms of load coefficient to the case in which there is no connection between the roof structure and the walls. With regards to the triumphal arch results, the limit analysis results are also in agreement with the numerical ones. Firstly, the plastic hinge formation is quite near the main crack development. Secondly, the formation of the plastic hinge on the base leads to the rotation of the rigid block which can create stress concentrations in the connection with other elements, which is visible on the numerical results (Fig. 16b).

For the lowest coefficient factor achieved, the structural system was converted to an equivalent system with a single degree of freedom with a spectral acceleration that activates the mechanism of $0.190 \mathrm{~g}$. According to OPCM code [26] the safety verification is satisfied when the spectral acceleration for the activation of the mechanism is greater than the acceleration of the elastic spectrum. The acceleration of the elastic spectrum was calculated according to the New Zealand code [40], resulting in a value of $0.146 \mathrm{~g}$. Comparing the demand and the capacity accelerations, it becomes evident that the safety verification is not satisfied, which again is in agreement with the numerical pushover analyses.

\section{CONCLUSIONS}

The seismic assessment of St James Church, before and after the damage due to Christchurch earthquake in New Zealand, was presented. Two numerical models were prepared using the finite element approach and calibrated according to the dynamic identification tests and the visual inspection carried out in situ, which provided extensive crack patterns. Afterwards, pushover analyses were performed for both the damaged by the earthquake model and the undamaged model.

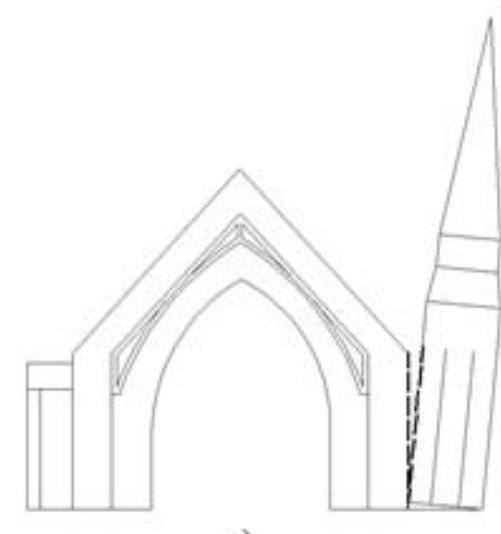

a)

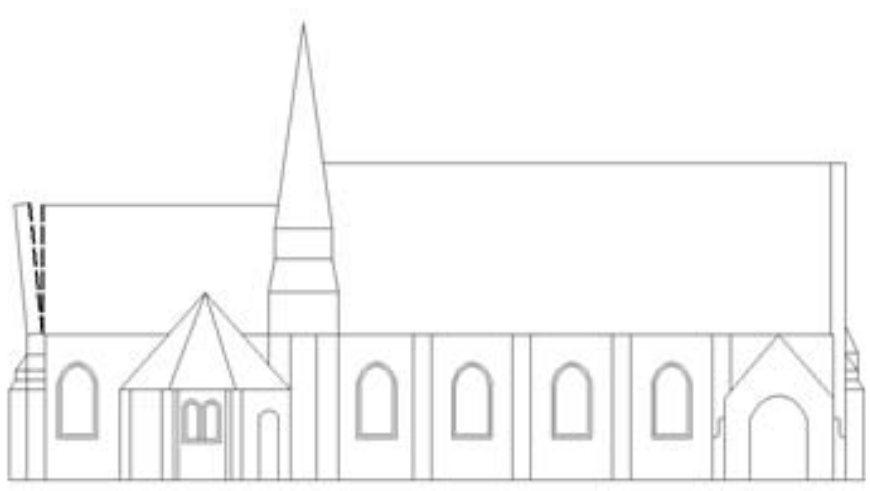

b)

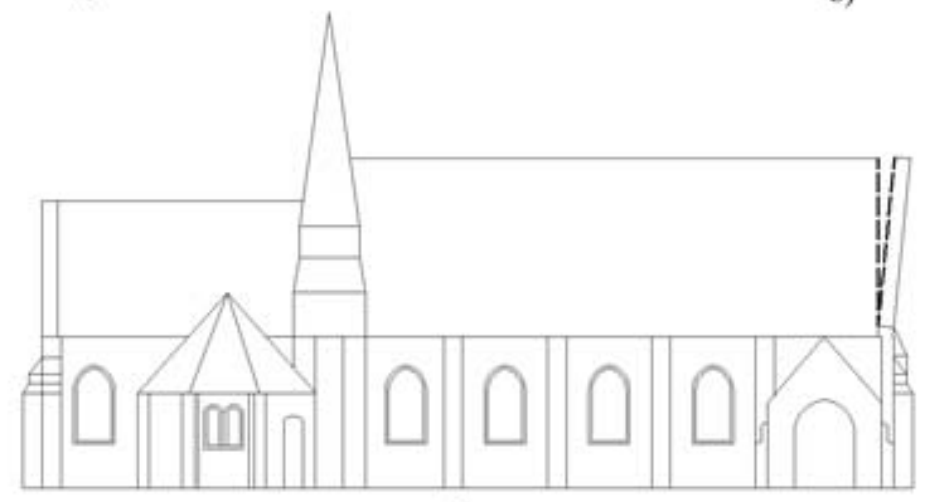

c)

Fig. (22). Out-of-plane collapse mechanisms: a) Overturning of the bell tower; b) Overturning of the east facade tympanum and c) Overturning of the west facade tympanum. 


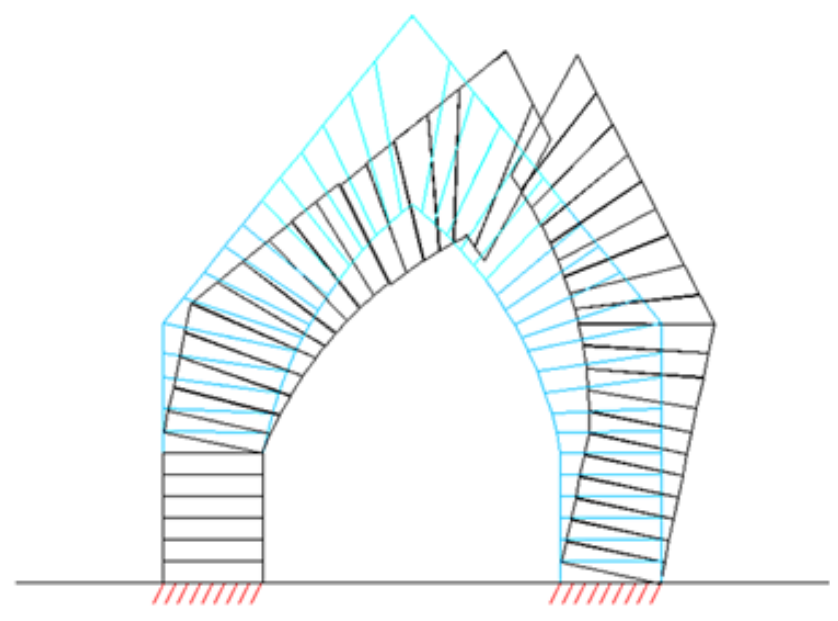

Fig. (23). In-plane collapse mechanism of the triumphal arch [35].

It is noted that dynamic identification of the damaged church was carried out and this allowed calibration of a finite element model with extensive damage, thus increasing the reliability of the subsequent analysis. Considering the results related to the Church's seismic assessment and pushover analyses, an evident conclusion should be made: the capacity of the Church is now relatively low (only $0.20 \mathrm{~g}$ ) and insufficient for the local seismic hazard, meaning that repair is needed.

Regarding the analysis results of the undamaged model, before having suffered the effects of the earthquake, these were evaluated and compared not only with the crack patterned due to the earthquake damage, but also with the previous analysis. According to the results, the PGA supported for the structure originally was around $0.40 \mathrm{~g}$, with the capacity being determined by the transverse church direction, which means that the earthquake reduced the capacity to the half. In the damaged structure, the capacity is determined by out-of-plane collapse of the gable walls. The damage obtained in the pushover analysis is in reasonable agreement with the damages observed in the structure. Still, out-ofplane damage of the gable walls was not found in the analysis and rotation of the limiting capacity from transverse direction, in the undamaged configuration, to longitudinal direction, in the damaged configuration, was found. This seems to indicate that pushover analyses are somewhat incorrect in terms of defining the failure modes of masonry structures without box behavior, requiring caution when used in engineering applications.

Despite the fact that limit analysis does not provide deformability information, it predicts the ultimate load and gives a relevant information about the failure mechanisms, which is of utmost importance for engineers that are assessing structural safety. Limit analysis was applied to the Church with the aim of evaluating its main collapse mechanisms and verifing its safety according to the NZ code. Good agreement between the limit analysis results and the numerical pushover results was achieved.

\section{CONFLICT OF INTEREST}

The authors confirm that this article content has no conflicts of interest.

\section{ACKNOWLEDGEMENTS}

The first and last authors gratefully acknowledge the support of the Portuguese Science and Technology Foundation (FCT) by the grant No. SFRH/BD/71599/2010 and SFRH / BD / 62301 / 2009.

\section{REFERENCES}

[1] S. Lagomarsino, "On the vulnerability assessment of monumental buildings," Bull. Earthquake Eng., vol. 4, no. 4, pp. 445-463, Sep. 2006.

[2] M. Betti and A. Vignoli, "Assessment of seismic resistance of a basilica-type church under earthquake loading: modelling and analysis," Adv. Eng. Softw, vol. 39, no. 4, pp. 258-283, Apr. 2008.

[3] P. Lourenço, "Computations on historic masonry structures," Prog. Struct. Eng. Mater., vol. 4, no. 3, pp. 301-319, Jul. 2002.

[4] P. B. Lourenço, N. Mendes, L. Ramos, and D. V. Oliveira, "Analysis of Masonry Structures Without Box Behavior," Int. J. Architect. Herit., vol. 5, no. 4-5, pp. 369-382, Jul. 2011.

[5] G. Magenes, "A method for pushover analysis in seismic assessment of masonry buildings," in Proceedings of the Twelfth World Conference on Earthquake Engineering, Auckland, New Zealand, 2000, pp. 1-8.

[6] P. Fajfar and M. Eeri, "A Nonlinear Analysis Method for Performance Based Seismic Design," Earthquake Spect., vol. 16, no. 3, pp. 573-592, 2000.

[7] S. Antoniou and R. Pinho, "Development and verification of a displacement-based adaptive pushover procedure," J. Earthquake Eng., vol. 8, no. 5, pp. 643-661, 2004.

[8] S. Schnept, L. Stempniewski, and D. Lungu, "Application of the Capacity Spectrum Method for Seismic Evaluation of Structures," in International symposium on strong vrancea earthquakes and risk mitigation, 2007, pp. 378-382.

[9] D. Vamvatsikos and C. A. Cornell, "Incremental dynamic analysis," Earthquake Eng. Struct. Dyn., vol. 31, no. 3, pp. 491514, Mar. 2002.

[10] M. J. N. Priestley, "Performance based seismic design," in 12th World Conference on Earthquake Engineering, 2000, vol. 1, no. 1, pp. $1-22$.

[11] S. S. Dyavanal and S. A. Annigeri, "Performance based seismic evaluation of multistory buildings with openings in infill walls," Protection of Historical Buildings - PROHITECH 09 Proceedings of the International Conference on protection of Historical Building, PR. no. 2008, pp. 1471-1475, 2009.

[12] EC8, "Eurocode 8: Design of structures for earthquake resistance Part 1: General rules, seismic actions and rules for buildings," Euro. Stand., 1998.

[13] A. Penna, S. Cattari, and A. Galasco, "Seismic assessment of masonry structures by non-linear macro-element analysis," IV International Seminar on Structural Analysis of Historical Construction-Possibilities of Numerical and Experimental Techniques, vol. 2, pp. 1157-1164, 2004.

[14] FEMA, "Prestandard and commentary for the seismic rehabilitation of buildings," FEMA 356, no. November, 2000.

[15] S. A. Freeman, "The Capacity Spectrum Method as a Tool for Seismic Design," in 11th European on Earthquake Engineering, 1998.

[16] ICOMOS, Recommendations for the analysis, conservation and structural restoration of architectural heritage. Paris, France: International Scientific Committee for Analysis and Restoration of Structures of Architectural Heritage, 2005, pp. 1-39.

[17] P. B. Lourenço, "Anisotropic softening model for masonry plates and shells," Struct. Eng., vol. 126, no. 9, pp. 1008-1016, 2000.

[18] G. Milani, P. B. Lourenço, and A. Tralli, "3D Homogenized limit analysis of masonry buildings under horizontal loads," Eng. Struct., vol. 29, no. 11, pp. 3134-3148, 2007.

[19] P. B. Lourenço and J. A. Roque, "Simplified indexes for the seismic vulnerability of ancient masonry buildings," Construct. Build. Mater., vol. 20, no. 4, pp. 200-208, 2006.

[20] J. Ross, "Parish of Riccarton-St James' 1906-1999 - Faith and Vision," Riccarton St James' History, 1999. [Online]. Available: 
http://www.riccartonstjames.org.nz/history.html. [Accessed: 14Jun-2011].

[21] G. Wilby, "St James Riccarton Report - Post 22 February 2011 Earthquake Structural Assessment", Christchurch, 2011.

[22] DIANA 9.4, "DIANA, DIsplacement method Analyser, release 9.4, User's Manual." TNO DIANA Bv: The Netherland, 2009.

[23] J. S. Bendat and A. G. Piersol, Random data: Analysis and measurement procedures, $3^{\text {rd }}$ ed. John Wiley and Sons: New Jersey, 2000.

[24] Matlab, "MATLAB User Manual, The MathWorks - 7.7.0.471 (R2008b)." USA, 2008.

[25] L. F. Ramos, L. Marques, P. B. Lourenço, G. De Roeck, a. Campos-Costa, and J. Roque, "Monitoring historical masonry structures with operational modal analysis: Two case studies," Mech. Syst. Signal Proc., vol. 24, no. 5, pp. 1291-1305, Jul. 2010.

[26] 3274/2003 OPCM, "Primi elementi in materia di criteri generali per la classificazione sismica del territorio nazionale e di normative tecniche per le costruzioni in zona sismica (in Italian)," Rome, Italy, 2003.

[27] M. Marco, B. Gianluca, and M. R. Valluzzi, "Mechanical analysis for the assessment of the seismic capacity of masonry buildings' classes in the city center of sulmona (Italy)," Adv. Mat. Res., vol. 133-134, pp. 623-628, 2010

[28] S. Antoniou and R. Pinho, "Advantages and limitations of adaptive and non-adaptive force-based pushover procedures," J. Earthquake Eng., vol. 8, no. 4, pp. 497-522, 2004.

[29] L. F. Ramos and P. B. Lourenço, "Advanced numerical analysis of historical centers: A case study in Lisbon," Eng. Struct., vol. 26, no. 9, pp. 1295-1310, 2004.

[30] P. Lourenco, K. J. Krakowiak, F. M. Fernandes, and L. F. Ramos, "Failure analysis of Monastery of Jerónimos, Lisbon: How to learn from sophisticated numerical models," Eng. Fail. Anal., vol. 14, no. 2, pp. 280-300, Mar. 2007.
[31] P. B. Lourenço, "Recent advances in masonry structures: Micromodelling and homogenisation, In: Multiscale Modeling in Solid Mechanics: Computational Approaches," U. Galvanetto and M. H. Aliabadi, Eds. Imperial College Press: London, 2009, pp. 251-294.

[32] S. Lagomarsino, "A new methodology for the post-earthquake investigation of ancient churches," in 11th European Congress on Earthquake Engineering, 1998, pp. 1-12.

[33] "Linee guida per gli interventi di riparazione del danno e miglioramento sismico per gli edifici di culto e monumentali Allegato A.3.1," 2002.

[34] L. Binda, G. Cardani, A. Saisi, and M. R. Valluzzi, "Vulnerability analysis of the historical buildings in seismic area by a multilevel approach," Asian J. Civ. Eng., vol. 7, no. 4, pp. 343-357, 2006.

[35] A. O. Bustamante, "Seismic Assessment of Ancient Masonry Structures by Rigid Blocks Limit Analysis," PhD Thesis, University of Minho, 2003.

[36] A. Giordano, E. Mele, and A. D. Luca, "Assessment of the seismic capacity of triumphal arches," Historical Constructions, P. B. Lourenço, P. Roca (Eds.), Universidade do Minho: Guimarães, pp. 983-992, 2001.

[37] P. B. Lourenço, P. B., Trujillo, A., Mendes, N., \& Ramos, L. F. Seismic performance of the St . George of the Latins church : Lessons learned from studying masonry ruins. Eng. Struct., vol. 40, 501-518, 2012.

[38] F. Casarin, "Structural Assessment and Seismic Vulnerability Analysis of a Complex Historical Building," PhD Thesis, Università degli Studi di Padova, 2006.

[39] A. De Luca, A. Giordano, and E. Mele, "A simplified procedure for assessing the seismic capacity of masonry arches," Eng. Struct., vol. 26, no. 13, pp. 1915-1929, 2004.

[40] New Zealand Standard, Structural Design Actions - Part 5: Earthquake Actions-New Zealand. 2004.

This is an open access article licensed under the terms of the Creative Commons Attribution Non-Commercial License (http://creativecommons.org/licenses/ by-nc/3.0/) which permits unrestricted, non-commercial use, distribution and reproduction in any medium, provided the work is properly cited. 